\title{
Evaluation of the Strategy of Utilization and Conservation of Freshwater Crab
}

\section{(Crustacea: Decapoda: Brachyura)}

\author{
Rupert C. Akpaniteaku \\ Department of Biological Science, Evangel University Akaeze, P.m.B. 129 Abakaliki, Ebonyi State Nigeria \\ *Corresponding Author: Rupert C. Akpaniteaku, Department of Biological Science, Evangel University \\ Akaeze, P.m.B. 129 Abakaliki, Ebonyi State Nigeria
}

\begin{abstract}
Crabs are crustacea of significant nutrition and medicinal values, with many species inhabiting aquatic and terrestrial environment. Further exploration of vast region of the globe could reveal many more species than already identified. Gradient of species richness could be evident from mangrove forest through savanna to desert region with perennial water source. Freshwater crabs are sensitive to pollution silting and deforestation, which some time result in redistribution outside natural habitats. Dramatic change in habitat could lead to rapid decline in population. Some threatening conditions such as agriculture, housing and industrial development have tampered with rich diversity of species in most habitats around the globe. Habitat restriction due to environmental degradation could be a major threat to local population and species diversity. Monitoring of the population and integrity of range and identification of threatened species are worthwhile conservation efforts. Land utilization for various economic purposes should however be in agreement with recruitment conditions of endangered species. Conservation strategy might also consider such biological aspects that promote reproduction and cultivation of the crab species.
\end{abstract}

Keywords: Global, Sustainable, Utilization, Conservation, Freshwater Crab.

\section{INTRODUCTION}

Crabs are edible crustacean like shrimp, prawns, crayfishes and lobsters which comprise major sources of nutrients. As good source of food and medicinal component, crabs play important role in the food chain of the ecosystem. Crabs are consumed as food in many countries. When compared with fish, they rank third after shrimp and lobster (Savad and Raghavan, 2001) ${ }^{1}$. They are found in aquatic and terrestrial environment, and irrespective of evolutionary adaptation return to water to deposit their brood. In Africa, they are important aquatic organisms, and very many species are found in all types of freshwater habitats (Dobson, 2004) ${ }^{2}$. There are many species of freshwater crabs that are grouped in two genera (Potamon and Potamonautes), and two families (Potamonidae and Patamonautidae) in Africa. Basic information gathering, such as abundance and distribution is an important approach in quantifying their role in fresh water ecosystem (Cumberlidge, 2011) ${ }^{3}$. Some of the crabs found along inland rivers need to return to the sea to reproduce (Connell and Robertson, 1986) ${ }^{4}$. The underside of the crab is used to establish gender of the species. The abdomen is folded under the cephalothorax and outline of the abdomen of the male is narrow triangle and two pairs of gonopods revealed if the abdomen is peeled back. The abdomen of the female is widened and peeling it back reveals four pairs of feathery appendages, the pleopeds. Several marine species have been encountered in freshwater near the coast, and some occur as adults in freshwater wet lands and cannot be classed as true freshwater crabs (Dobson, 2004) ${ }^{2}$. Population status of the various habitats; generic divergence and conservation of threatened crab species; have been reviewed by many brachyuran investigators. Some of the investigations were centred on ecosystems in Africa. The need for global review of conservation with reasonable attention to sustainability and strategy was recently observed. 
Evaluation of the Strategy of Utilization and Conservation of Freshwater Crab (Crustacea: Decapoda: Brachyura)

\section{FreshWATER Crab}

Crabs are found in a wide variety of aquatic and terrestrial habitats. They are present in almost all the freshwater bodies from fast-flowing to sluggish rivers and streams, as well as in swamps, stagnant ponds and rice fields. Some species are adapted to live in leaf axils, tree holes and caves. Potamids are aquatic crabs adapted to live in freshwater, and are not able to survive for a long time in marine environment, while crabs like parathelphusids are more tolerant of salt water conditions, and can survive in saline condition for short period of time. Terrestrial species can be found in habitats well away from water sources, climbing trees and even on among litter on the forest floor $(\mathrm{Ng}$ and Tay 2001; Cumberlidge et al, 2005) ${ }^{5,6}$. Potamonautes species can be found beyond this environment even among aquatic vegetation and debris. By avoiding high-current environment, they are able inhabit flowing water (Akpaniteaku, 2016) ${ }^{7}$. An overview of freshwater crab fauna in Africa indicated that they are the most important species inhabiting inland waters (Table 1). The habitats range from mountain streams to large low land rivers and smaller water bodies (Cumberlidge, 2011) ${ }^{3}$. Adult crabs from African fresh water can cover a wide range of sizes. Male and female within a species grow at similar rates and adult males are required to ensure correct identification (Dobson, 2004) ${ }^{2}$. Large areas of vast region are yet to be explored and new species of freshwater crabs are going to be discovered as efforts are intensified in collecting them in remote areas (Daniels et al. 2001) ${ }^{8}$. The role of various crab species in aquatic ecosystem or their population densities in African river has not been properly understood. However, biomass values are sometimes underestimated and problem of population estimates are well known in freshwater crabs

Table1: Review of some of the conservation campaign for freshwater crabs

\begin{tabular}{|c|c|c|c|c|c|c|}
\hline \multirow[b]{2}{*}{ Location } & \multicolumn{2}{|c|}{ Type of Crab } & \multirow[b]{2}{*}{ Objective } & \multirow[b]{2}{*}{ Activity } & \multirow[b]{2}{*}{ Source } & \multirow{2}{*}{$\begin{array}{c}\text { Valuation } \\
\text { range } \\
(1-5)\end{array}$} \\
\hline & Mud crab & $\begin{array}{l}\text { River } \\
\text { Crab }\end{array}$ & & & & \\
\hline Africa & - & $\begin{array}{l}\text { Potamonaut } \\
\text { es spp }\end{array}$ & Exposition & $\begin{array}{l}\text { Subject } \\
\text { review }\end{array}$ & Dobson, $2004^{2}$ & 3 \\
\hline $\begin{array}{l}\text { East Africa } \\
\text { (Kenya) }\end{array}$ & - & $\begin{array}{l}\text { Potamonaut } \\
\text { es odhneri }\end{array}$ & Abundance & $\begin{array}{l}\text { Quantificati } \\
\text { on }\end{array}$ & $\begin{array}{l}\text { Dobson et al., } \\
2007^{11}\end{array}$ & 2 \\
\hline $\begin{array}{l}\text { West Africa } \\
\text { (Nigeria) }\end{array}$ & $\begin{array}{l}\text { Potaamon } \\
\text { ebonyicum }\end{array}$ & - & $\begin{array}{l}\text { Feed } \\
\text { acceptance }\end{array}$ & Culture trial & $\begin{array}{l}\text { Akpaniteaku, } \\
2013^{14}\end{array}$ & 2 \\
\hline “ & $\begin{array}{l}\text { Potaamon } \\
\text { ebonyicum }\end{array}$ & - & $\begin{array}{l}\text { Ovary } \\
\text { strategy }\end{array}$ & $\begin{array}{l}\text { Reproductio } \\
\mathrm{n} \text { aspect }\end{array}$ & $\begin{array}{l}\text { Akpaniteaku, } \\
2015^{15}\end{array}$ & 3 \\
\hline “ & - & $\begin{array}{l}\text { Potamonaut } \\
\text { es ebiaensis }\end{array}$ & $\begin{array}{l}\text { Aquaculture } \\
\text { potential }\end{array}$ & Assessment & $\begin{array}{l}\text { Akpaniteaku, } \\
2016^{17}\end{array}$ & 1 \\
\hline South Africa & - & $\begin{array}{l}\text { Potamonaut } \\
\text { es spp }\end{array}$ & $\begin{array}{l}\text { Conservation } \\
\text { status }\end{array}$ & Assessment & $\begin{array}{l}\text { Cumberlidge and } \\
\text { Daiels, } 2007^{13}\end{array}$ & 1 \\
\hline Global & $\begin{array}{l}\text { Potamon } \\
\text { spp }\end{array}$ & $\begin{array}{l}\text { Potamonaut } \\
\text { es spp }\end{array}$ & $\begin{array}{l}\text { Diversity } \\
\text { status }\end{array}$ & Assessment & $\begin{array}{l}\text { Yeo et al-, } \\
2008^{16}\end{array}$, & 1 \\
\hline Global & $\begin{array}{l}\text { Potamon } \\
\text { spp }\end{array}$ & $\begin{array}{l}\text { Potamonaut } \\
\text { es spp }\end{array}$ & $\begin{array}{l}\text { Brood } \\
\text { improvement }\end{array}$ & $\begin{array}{l}\text { Subject } \\
\text { review }\end{array}$ & $\begin{array}{l}\text { Azra } \\
2015^{17}\end{array}$ et al. & 3 \\
\hline
\end{tabular}

1 Very high, 2 high, 3 low, 4 poor, 5 very poor

\section{Distribution PATTERN}

Many crab species have been redistributed outside their natural habitats. Boundary between thickly forested area and mud flats has been identified as environment that supports high density of aquatic crab. Different species could be present in any one location, but few of them may be responsible for the dominant percentage of the population. The need to assess development indices, immediate threat of the environment and conservation efforts (Fig I.) could be a long-term consideration (FAO, 2011 and Akpaniteaku 2014) $)^{9,10}$. The population in the forest environment sometimes constitute mainly of small juveniles, which are absent from agricultural sites. Mud crabs account for about $70 \%$ of total higher invertebrate population from forest and shaded farming environment, and about $40 \%$ in open cultivable sites. The reproductive process in crabs possibly occurs mainly in forested area, serving as recruitment source for the biomass downstream in arable areas (Dobson et al, 2007) ${ }^{11}$. Survey of 
many locations in geographically restricted areas might determine regional abundance and distribution relative to other higher invertebrates. Clusters of mountain species may be widely separated but are closely related to each other than the lowland species. The size of high-altitude species within the same region can be an evidence of ancestral relationship (Daniels et al, 2002) ${ }^{12}$.

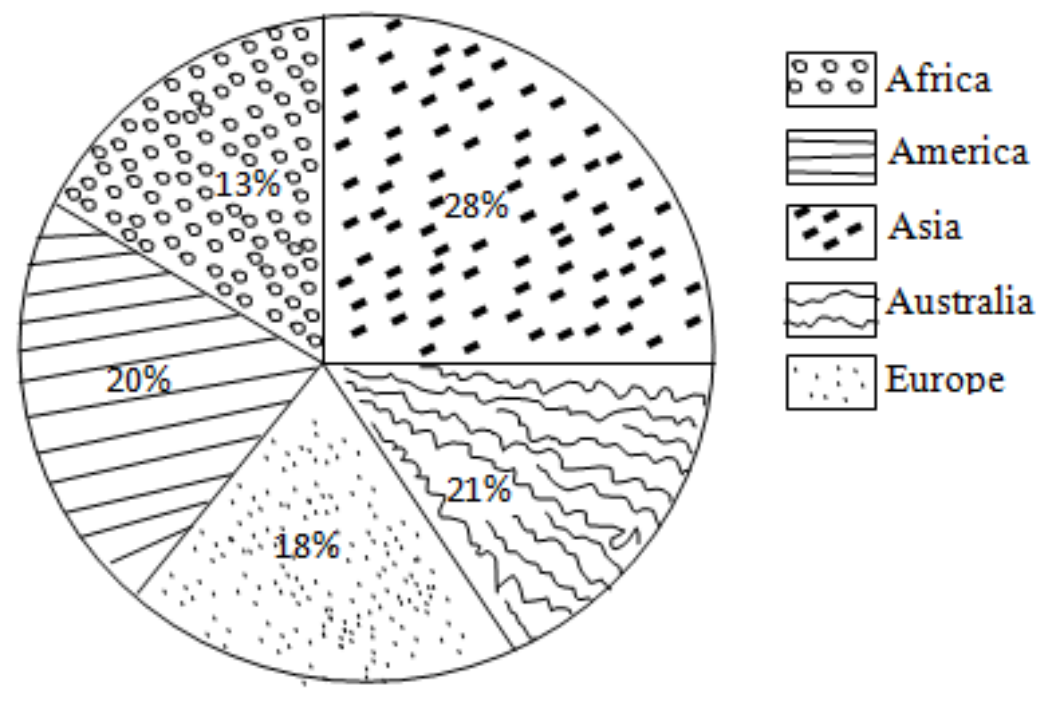

Fig1: Global effort to sustainable conservation of freshwater crab (Estimated)

Endemic species are often not known in vast area of any region with low species richness. Freshwater crab diversity is also low in deserts (with endemic species) where they are restricted to perennial water source (Cumberlidge and Daniels, 2007) ${ }^{13}$. They are the members of genus potamonautes with some poorly understood taxonomic groups including their altitudinal distribution range. They are widely spread in some areas of the region including all of those with undisturbed vegetation. The ecological importance of crab species in undisturbed environment is a demonstration of abundance and role in most of the streams in which they occur (Dobson et al, 2007) ${ }^{11}$. Narrowly distributed species could be adversely affected by dramatic changes in habitat, resulting from land use, and even suffer rapid decline and extinction within relatively short time. The crab species found in protected area within range may face no threat for a long period of their existence.

\section{Conservation Strategy}

Rich diversity of crab species in stream and major river basins especially those that flow through low land forest and forested high lands, is highly associated with an ecoregion. With a few exceptions, relationship between ecoregion and crab distribution pattern is not close. Correlation instances in distribution and boundaries of ecoregion are only abound in restricted crabs (Cumberlidge, 2011) ${ }^{3}$. Sensitivity of freshwater crabs to silting and pollution are not yet clear, elsewhere around the globe they could be facing challenges of survival. Endemic crab species has specific habitat requirement which determine occurrence such as muddy-bottomed area, sandy or rocky environment. Restricted habitat requirement has been observed in most species that appear in high gradient streams or large or more sluggish rivers (Dobson, 2004) $)^{2}$. Crab species are potentially subject to natural and human impacts such as habitat destruction or pollution. These conditions could be threatening if they were not regularly found in protected area or protected part of its range (Cumberlidge and Daniels 2007) ${ }^{13}$. Common crab species have wide range distribution in lakes, rivers and mountain streams, and are tolerant of changes in terrestrial forms that affect aquatic ecosystems. Habitat destruction caused by agricultural activities, demands of industrial development and devastation of rivers for the creations of hydroelectric power are threats to some of the freshwater crabs. Steps have been taken toward identification of threatened species within some African regions and toward development of conservation strategy for endemic freshwater crabs (Table I). Restricted range of species from the region including habitat loss due to human activities is worrisome in respect of long-term security of the crustacean. Integrity of site and habitats are the primary aim of conservation as well as close monitoring of the key populations (Cumberlidge and Daniels 2007) ${ }^{13 .}$ 
Evaluation of the Strategy of Utilization and Conservation of Freshwater Crab (Crustacea: Decapoda: Brachyura)

\section{RECOMMENDATION}

Sustainable conservation is becoming feasible as biology and cultivation aspects of the crustaceans are better understood. Some regional species have shown tolerance to supplement feed stuff and various cultivation requirements in captivity (Table 2). Careful application of pest management chemicals and responsible environmental restructuring are necessary for restoration and healthy resource management. This is mainly because agricultural development activities have taken much toll on crab population in various regions. Most of the recently quoted species are adaptable to captivity, which is the basis for sustainable approach to conservation. Massive interest in cultivation could therefore support genuine conservation plan with adequate sensitization through extension workers.

Table2: Global estimation of cultivable crab species

\begin{tabular}{|c|c|c|c|}
\hline \multirow[t]{2}{*}{ Location } & \multicolumn{2}{|c|}{ Number of Cultivable Crab Species } & \multirow[t]{2}{*}{ Source } \\
\hline & Cultivated (No) & Experimented (No) & \\
\hline Africa & $2 *$ & 3 & $\begin{array}{l}\text { FAO, 2011; Akpaniteaku } 2013 \text { and 2016; Mirera and } \\
\text { Moksnes, 2015, 14, 15, 18 }\end{array}$ \\
\hline America & 1 & 1 & Blue Crab Farms (undated) ${ }^{19}$ \\
\hline Asia & $3 *$ & 1 & $\begin{array}{l}\text { FAO, 2011; Banglapedia, 2012; The Fish Site } \\
\text { (undated) } 9,20,21\end{array}$ \\
\hline Australia & $2 *$ & 1 & FAO, 2011,; Business Queensland 2016,22 \\
\hline Europe & 1 & - & The Fish Site (undated) ${ }^{21}$ \\
\hline
\end{tabular}

\section{CONCLUSION}

Conservation of various species of crabs through responsible utilization of land is dependent on renewed effort in housing and industrialization with their resultant wastes and polluted environment. Additional effects of climate change might continue to counter remedial and sustainable activities. However, wild population could be significantly restored by combining sustainable exploitation with serious intervention in area of cultivation.

\section{REFERENCES}

[1] Savad, A.M. and Raghavan, P.R., Mud crab culture and fattening techniques, status and prospects, seafood. Exp. Journal 32(11) Pp. 25-29 (2001).

[2] Dobson, M., Freshwater crabs in Africa freshwater forum (21) Pp 3-26 (2004).

[3] Cumberlidge, N., Chapter 6. The status and distribution of freshwater crabs, pp. 71-78. In: Brooks, E.G.E., Ellen, D.J. and Darwall, W.R.T. (compilers). 2011. The status and distribution of freshwater Biodiversity in central Africa. (2011) Glands, Switzerland and Cambridge, UK: IUCN: i-ix+ Pp 140 (2011).

[4] Connell, A.D. and Robertson, W., Recent records of megalopae of crab Varuna litterata (fabr.) entering Natal estuaries. South African Journal of Zoology (21) Pp 184-185 (1986).

[5] Ng, P.K.L. and Tay, F.W.M., The freshwater crabs of Sri Lanka (Decapoda: Brachyura: paratelphesidae). Zeylanica (6) Pp 113-199 (2001)

[6] Cumberlidge, N., Fenolio, D.B., Walvoord, M.E. and Stout, J., Tree climbing crabs (Potamonautidae and sesarmidae) from phylotelimic microhabitats in rainforest canopy in Madagascar. Journal of Crustacean Biology (25) Pp 302-308 (2005).

[7] Akpaniteaku R.C., Experimentation on the river crab (Potamonaute ebiaensis) aquaculture in Ebonyi State, Nigeria; preliminary assessment. International journal of Fisheries and Aquatic Studies 4(5) Pp 468-471 (2016)

[8] Daniels s.R.., Stewart, B.A. and Burmeister, L., Geographic patterns of genetic and morphological divergence among populations of a river crab (Decapoda: Potamonautidae) with the description of a new species from mountains in the Western Cape. South Africa Zool scripta 30 Pp 181-197 (2001).

[9] F.A.O., Mud crab aquaculture: A practical manual. FAO Technical paper (567) 78 (2011).

[10] Akpaniteaku R.C., Assessment of the approach and potential of mud crab aquaculture. Global Journal of Fisheries and Aquaculture 2(3) Pp 148-151 (2014).

[11] Dobson, M., Magana, A.M., Mathooko, J.M. and Ndegwa, F.K., Distribution and abundance of freshwater crabs (Potamonautes spp.) in rivers draining Mt Kenya, East Africa. Fundamental and Applied Limnology 168(3) Pp 271-279 (2007). 
Evaluation of the Strategy of Utilization and Conservation of Freshwater Crab (Crustacea: Decapoda: Brachyura)

[12] Damiels, S.R., Stavart, B.A., Gouws, G., Cunningham, M. and Mathee, C.A., Phylogenetic relationships of the Southern African freshwater crab fauna (Decapoda: Potamonautidae: Potamonautes) derived from multiple data sets reveal biogeographic patterning. Molecular physogenetics and Evolution 25 Pp 511-523 (2002).

[13] Cumberlidge, N. and Daniels, S.R., A conservation assessment of the freshwater crabs of Southern Africa (Brachyura: Potamonautidae). African Journal of Ecology 46(1) Pp 74-79 (2007).

[14] Akpaniteaku R.C., A Study on cultivability and feeding of mud crab (Potamon ebonyicum) in Ebonyi State, Nigeria. International Journal of Research and Advancement in Bioscience 3(2) Pp 132-135(2013).

[15] Akpaniteaku R.C., Aspects of reproduction and the condition of gravid mud crab (crastacea: Brochyura: Potamon) in Ebonyi State Nigeria. International Journal of Research Studies in Biosciences 3(1) Pp 104109 (2015).

[16] Yeo, D.C.J., Ng, P.K.L., Cumberlidge, N., Magalhaes, C., Daniels, S.R., Campes, M.R., Global diversity of crabs (crustacean: Decapoda: Brachyara) in freshwater. Hydrobiologia (595) Pp 275-286 (2008).

[17] Azra, M.N., Abol-Munafi, A.B. and Ikhwanaddin, M., A review of broodstock improvement to Brachyaran crab: Reproductive Performance International Journal of Aquaculture 5(38) Pp 1-10 (2015)

[18] Mirera, D.O. and Moksnes, P.O., Aquacult Int 23: 155. https://doi.org/1o.1007/s10499-014-9805-3 (2015).

[19] Blue Crab Farm, Blue crab farming. Bluecrabfarms.com/blue-crab-aquaculture (undated).

[20] Bauglapedia crab en.banglapedia.org/index.php?title=crab (2012).

[21] The fish site culture of aquatic species-Chinese river crab: http://www.thefishsite.com/articles/859/cultureaquaticspecies (undated).

[22] Business Queens land. Growing mud crabs. https://www.business.gld.gov.au/ Industries/Farm-fishingforestry/fisheries/aquaculture/species/ mud-crab/ growing (2016).

Citation: R. C. Akpaniteaku, "Evaluation of the Strategy of Utilization and Conservation of Freshwater Crab (Crustacea: Decapoda: Brachyura)", International Journal of Innovative Studies in Aquatic Biology and Fisheries, vol. 3, no. 2, p. 18-22, 2017. http://dx.doi.org/10.20431/2454-7670.0302004

Copyright: (C) 2017 Authors. This is an open-access article distributed under the terms of the Creative Commons Attribution License, which permits unrestricted use, distribution, and reproduction in any medium, provided the original author and source are credited. 